\title{
Synthesis and ultrastructural observation of arbutoid mycorrhizae of black truffles (Tuber melanosporum and T. aestivum)
}

\author{
Francesca Ori ${ }^{1} \cdot$ Marco Leonardi $^{1} \cdot$ Antonella Faccio $^{2} \cdot$ Fabiano Sillo $^{2} \cdot$ Mirco lotti $^{1}$ (I) $\cdot$ Giovanni Pacioni ${ }^{1}$. \\ Raffaella Balestrini ${ }^{2}$
}

Received: 27 April 2020 / Accepted: 18 August 2020 / Published online: 24 August 2020

(C) The Author(s) 2020

\begin{abstract}
Arbutus unedo (the strawberry tree) is a Mediterranean shrub which forms arbutoid mycorrhizae with a variety of Asco- and Basidiomycetes. After the discovery of the mycorrhizal symbiosis between A. unedo and Tuber borchii, in this study, arbutoid mycorrhizae were synthetized in greenhouse with Tuber aestivum and Tuber melanosporum. Six months after inoculation, both species colonized the roots of all inoculated A. unedo seedlings, but mature mycorrhizae were only observed after 12 months. Ultrastructure analysis of Tuber arbutoid mycorrhizae was described for the first time, showing, as observed in typical endosymbiosis, a rearrangement of host cells and the creation of an interface compartment with both truffle species. Immunolabelling experiments suggested that pectins are not present in the interface matrix surrounding the intracellular hyphae. Thus, the ability to establish symbiosis with $A$. unedo seems to be a common feature in the genus Tuber, opening up the possibility to use this plant for mycorrhization with valuable truffles. This could represent an important economic opportunity in Mediterranean areas by combining the production of truffles, edible fruits and valued honey.
\end{abstract}

Keywords Truffle $\cdot$ Strawberry tree $\cdot$ Co-cropping $\cdot$ Morphotyping $\cdot$ TEM $\cdot$ Immunolabelling

\section{Introduction}

Truffles are hypogeous fungi belonging to the genus Tuber (Ascomycota, Pezizales) that produce edible ascomata. Bonito et al. (2010) estimated that Tuber contains a minimum of 180 species, some of them with high commercial value. The most famous and expensive truffle species are Tuber magnatum Picco and Tuber melanosporum Vittad., better known as the Italian white truffle and the Périgord truffle, respectively. Of great interest are also other species such as Tuber aestivum Vittad. and Tuber borchii Vittad. Cultivation

Electronic supplementary material The online version of this article (https://doi.org/10.1007/s00572-020-00985-5) contains supplementary material, which is available to authorized users.

Mirco Iotti

mirco.iotti@univaq.it

1 Department of Life, Health and Environmental Sciences, University of L'Aquila, via Vetoio, Coppito 1, 67100 L'Aquila, Italy

2 National Research Council, Institute for Sustainable Plant Protection, Viale Mattioli 25, 10125 Torino, Italy of these edible truffles is becoming increasingly important in their native European countries as well as outside Europe where these fungi do not naturally grow (Zambonelli et al. 2015). Valuable Tuber species can grow in a variety of soil and climate conditions and can establish ectomycorrhizal (ECM) relationships with a broad range of host plants. They are reported to be symbionts predominantly of woody plants and shrubs such as oaks, hazels, pines and rockrose. However, T. aestivum, T. melanosporum and T. borchii have also been found in symbiotic association (as mycorrhizae or endophytes) with hosts that do not form ectomycorrhizae (Selosse et al. 2004; Ouanphanivanh et al. 2008; Gryndler 2016; Lancellotti et al. 2016; Schneider-Maunoury et al. 2018, 2020). Arbutus species (Ericaceae) form mycorrhizal interactions (i.e. arbutoid mycorrhizae) with fungi involved in ECM associations (Molina and Trappe 1982). Several ultrastructural studies have shown that arbutoid mycorrhizae are very similar to ectomycorrhizae with the exception of the intracellular penetration. As in the ectomycorrhizae, arbutoid associations produce an intercellular Hartig net, usually restricted to the outer layer of root cells, and a fungal sheath can be present although with a different thickness depending on the fungus involved in the association (Massicotte et al. 
1993). As the main difference, in arbutoid mycorrhizae, fungal hyphae colonize the rhizodermal cells and fill them with hyphal coils (Massicotte et al. 1993). Kennedy et al. (2012) identified two Tuber species as fungal partners in arbutoid mycorrhizae formed with Arbutus menziesii Pursh, while Lancellotti et al. (2014) and Plácito et al. (2018) described arbutoid mycorrhizae between T. borchii and Arbutus unedo L. either recovered from the wild or synthetized in greenhouse. However, it needs to be demonstrated that this plant can be successfully used for large-scale programmes of truffle mycorrhization. Arbutus unedo, the strawberry tree, is a native Mediterranean species, naturally spread along the Atlantic coasts of some European countries including Ireland and France (Santiso et al. 2015). Since it responds well to the conditions of Mediterranean summers, such as high temperature, low humidity and water stress, it is also considered an alternative for revegetation and restoration projects in the Mediterranean basin (Navarro et al. 2007a). Besides its use in gardening (Navarro et al. 2007b), A. unedo is used in tannery and medicine, and its edible fruits can be consumed fresh or in processed products like alcoholic beverages, jams, jellies and compotes (Lim 2012; Morgado et al. 2018).

While the anatomy and ultrastructure of A. unedo-Laccaria amethystina Cooke arbutoid mycorrhizae have been already reported (Münzenberger et al. 1992) as well as the description of the mycorrhizae that developed between A. unedo and an unknown ascomycete (Fusconi and Bonfante-Fasolo 1984), at our knowledge, no information has been reported on the ultrastructural features of $A$. unedo roots colonized by a Tuber species. Our hypothesis was that the capacity of establishing symbiosis with Arbutus is a common feature in the genus Tuber and that the truffle arbutoid mycorrhizae have different features from the corresponding ectomycorrhizae, a difference that can be ascribed to the plant species involved. Interestingly, Fusconi and Bonfante-Fasolo (1984) suggested that arbutoid mycorrhizal structure should be considered a subtype of the ericoid mycorrhizal type. This paper reports on a morphological analysis of arbutoid mycorrhizae of A. unedo synthetized in pots using two different truffle species, i.e. T. aestivum and T. melanosporum. In addition, electron microscopy observations allowed us to provide a detailed description of the ultrastructural features in the two mycorrhizal types.

\section{Materials and methods}

\section{Plant material and inoculum production}

Seeds of A. unedo were collected from a single plant, sited in a private garden in Roseto degli Abruzzi (Italy). Seeds were surface sterilized in $1 \%$ sodium hypochlorite solution for $1 \mathrm{~h}$ and then rinsed with tap water. Seedlings were grown in a sterile peat moss/vermiculite mix (1:1) for about 5 weeks before inoculation (3-5 true leaves present). Arbutus seedlings were inoculated with spores of $T$. aestivum and T. melanosporum. The spore suspensions were obtained by crushing fresh ascomata with a Waring blender $7011(18,000$ $\mathrm{rpm}$ ) and suspending them in sterile water. Ascomata were previously brushed under tap water and surface flame sterilized for a few seconds. Twenty seedlings ( 10 for each truffle species) were transplanted into plastic pots with a mix of vermiculite $(50 \%)$, river sand $(40 \%)$ and peat moss $(10 \%)$ and then inoculated with an aliquot of about $1 \times 10^{6}$ spores, injected close to the roots of each plant. Inocula were prepared measuring spore density of the suspension by a haemocytometer. Ten seedlings were not inoculated and used as controls. The plants were grown at $22 \pm 2{ }^{\circ} \mathrm{C}, 80 \%$ relative humidity and 14-h photoperiod and watered twice a week.

\section{Evaluation of root colonization and molecular analyses}

Root colonization was evaluated 6 and 12 months after inoculation. Roots were washed in sterile water and examined under a stereomicroscope equipped with a camera (Leica). Five root fragments for each plant (4-8 cm length) were examined to evaluate root colonization by $T$. aestivum and T. melanosporum. After collection of the root tips at the first time point (6th month), all seedlings were kept in the same pot and soil and grown for another 6 months. The colonization degree was measured by counting the number of infected and uninfected tips, and the result was expressed as a percentage. Morpho-anatomy of mycorrhizae was described following Agerer (1995). Three mycorrhizal tips for each Tuber species and seedling were stored in FAA (37\% formaldehyde: $70 \%$ ethanol/acetic acid, 5:90:5) at $4{ }^{\circ} \mathrm{C}$ pending morphometric analysis. Dimensions of 25 mycorrhizal tips (unramified ends) were measured for each species and time point ( 6 and 12 months).

One to three colonized tips per seedling were stored in sterile water at $-80{ }^{\circ} \mathrm{C}$ for molecular characterization. Confirmation of fungal identity was performed by applying species-specific primers of T. aestivum (Mello et al. 2002) and T. melanosporum (Rubini et al. 1998). Amplifications were carried out by applying the direct PCR technique (Iotti and Zambonelli 2006) according to which a microscopic mantle fragment is used as PCR target without prior DNA extraction.

\section{Anatomy and ultrastructure}

\section{Fixation, embedding and microscope observations}

Anatomy and ultrastructure of truffle arbutoid mycorrhizae were studied on longitudinal sections. Fresh mycorrhizae were fixed in $2.5 \%(\mathrm{v} / \mathrm{v})$ glutaraldehyde in $10 \mathrm{mM} \mathrm{Na}$-phosphate 
buffer ( $\mathrm{pH} 7.2)$ for $2 \mathrm{~h}$ at room temperature and then overnight at $4{ }^{\circ} \mathrm{C}$. After rinsing with the same buffer, they were dehydrated in an ethanol series (30, 50, 70 and 90\% for 15 min each step, and 2 times $100 \%$ for 20 min each step) at room temperature. Dehydrated ectomycorrhizae were infiltrated in 3:1 (v/v) absolute ethanol/London Resin White resin (Multilab Supplies) (E/LRW) for $1 \mathrm{~h}, 1: 1 \mathrm{E} / \mathrm{LRW}$ for $1 \mathrm{~h}$, 1:3 E/LRW for $1 \mathrm{~h}$ and $100 \%$ London Resin white overnight at $4{ }^{\circ} \mathrm{C}$ according to Balestrini et al. (1996). The mycorrhizae were then embedded in gelatine capsules and polymerized for $24 \mathrm{~h}$ at $60^{\circ} \mathrm{C}$. Semi-thin sections $(2.25 \mu \mathrm{m})$ were cut using an ultramicrotome and stained with $1 \%$ toluidine blue in $1 \% \mathrm{Na}$ borate. Mycorrhizal anatomy and mantle thickness were analysed under a microscope equipped with a camera (Leica). Ninety measurements $(30 \times 3$ mycorrhizal tips) were taken for each species, time point (6 and 12 months) and root tip position (proximal or distal part of tips).

For the ultrastructural observations, after the preparation of semi-thin sections $(1 \mu \mathrm{m})$ stained with $1 \%$ toluidine blue, ultra-thin sections $(0.05-0.07 \mu \mathrm{m})$ were cut and poststained with Uranyl Acetate Substituted (Agar Scientific, Stansted UK) and lead citrate before observation with Philips (Eindhoven, The Netherlands) CM 10 transmission electron microscope operated at $60-80 \mathrm{kV}$.

\section{Immunolabelling}

Ultra-thin sections were incubated for $15 \mathrm{~min}$ in normal goat serum diluted $1: 30$ in $0.05 \mathrm{M}$ Tris-HC1 buffer with $0.9 \%$ $\mathrm{NaCl}$ (TBS, $\mathrm{pH} 7.6$ ) and $0.2 \% \mathrm{BSA}$ and treated overnight with the different monoclonal antibodies (1:1 dilution) to localize pectins (JIM5, LM19, JIM7; CarboSource, https://www.ccrc. uga.edu/ carbosource/CSS_mabs7-07.html). After washing, they were incubated for $1 \mathrm{~h}$ with $15 \mathrm{~nm}$ of colloidal gold goat-anti-rat IgG complex (BBI Solutions, Crumlin UK) containing 1\% BSA (diluted 1:20 in TBS). Thin sections were then post-stained as described above (ultrastructural observations). Labelling specificity was determined by replacing the primary antibody with the buffer.

\section{Statistical analysis}

A two-way ANOVA with robust estimators (number of bootstrap samples $=5000$ ) procedure was used to compare mantle thickness at different positions and times after inoculation for both T. melanosporum and T. aestivum. A Wilcoxon signedrank test was used to assess significant differences between mantle thickness at different time points for each species, as well as to assess differences in mycorrhizal diameters and length. For all tests, differences were considered statistically significant with a probability level of $P \leq 0.05$. In order to assess the effect of time and species in terms of number of observed mycorrhizae, a two-way ANOVA with robust estimators (number of bootstrap samples $=5000$ ) was used, and mean separation was performed using the Tukey HSD test, adopting a probability level of $P \leq 0.05$. All tests were conducted by using $\mathrm{R}$ (basic and WRS2 packages).

\section{Results}

\section{Root colonization and morphology}

Six months after inoculation, all seedlings were found to be colonized by the inoculated truffle species with a mean value of $27 \pm 4 \%$ and $24 \pm 5 \%$ for $T$. aestivum and T. melanosporum, respectively. Root colonization increased to $57 \pm 17 \%$ and $46 \pm 16 \%$ after further 6 months of seedling growth. Significant effects of time, but not species, was determined on mycorrhizal colonization, which was significantly higher $(P \leq 0.05)$ for both species at 12 months compared with 6 months (Fig. 1S). All PCRs confirmed the identity of truffle mycorrhizae by producing species-specific amplicons of $402 \mathrm{bp}$ and $447 \mathrm{bp}$ for T. aestivum and T. melanosporum, respectively (data not shown). No other ectomycorrhizal fungi were found to colonize the roots of any A. unedo seedlings.

Mycorrhizae analysed 6 months after inoculation had a smooth mantle without cystidia regardless the truffle species. Rhizodermal cells and Hartig net were visible in transparency under fungal mantle forming a brown reticulum. Tuber melanosporum mycorrhizae had a higher number of cruciform ramifications (40\%) than T. aestivum (20\%). Most tips of T. aestivum were clavate (Fig. 2Sa), while those of T. melanosporum were mostly tapering without an evident mantle at the apex (Fig. 2Sb).

Tuber aestivum mycorrhizae were ochre in colour, with tips $435 \pm 83 \mu \mathrm{m}$ long and $195 \pm 35 \mu \mathrm{m}$ wide. Tuber melanosporum mycorrhizae were ochre-brown in colour, with tips $632 \pm 182 \mu \mathrm{m}$ long and $158 \pm 24 \mu \mathrm{m}$ wide. Twelve months after inoculation, mycorrhizae of both truffle species were mostly cruciform (> $90 \%$ ), clavate and ochre (distally) to brown (proximally), with abundant ( $T$. aestivum) or sparse ( $T$. melanosporum) cystidia (Fig. 1a, b). The size of tips increased in both T. melanosporum $(729 \pm 195 \mu \mathrm{m} \times 218 \pm 27 \mu \mathrm{m})$ and T. aestivum $(804 \pm 194 \mu \mathrm{m} \times$ $219 \pm 30 \mu \mathrm{m})$. Diameters and length of tips at 12 months were significantly different $(P \leq 0.05)$ from those at 6 months for T. aestivum, while only tip diameter significantly differed $(P \leq$ 0.05) over time for T. melanosporum (Fig. 3S).

\section{Anatomy and ultrastructure}

Microscopical observations showed that mycorrhizae of both species had a pseudoparenchymatous mantle with angular (type L) or epidermoid (type M) cells for T. aestivum and T. melanosporum, respectively. The semi-thin longitudinal sections of 6-month-old mycorrhizae showed the lumen of 
Fig. 1 Arbutoid mycorrhizae of T. aestivum $(\mathbf{a}, \mathbf{c}, \mathbf{e})$ and T. melanosporum (b, d, f) 12 months after inoculation. Bars correspond to $250 \mu \mathrm{m}$ for whole mycorrhizae (a, b) and $200 \mu \mathrm{m}$ (c, d) or $50 \mu \mathrm{m}(\mathbf{e}, \mathbf{f})$ for longitudinal sections
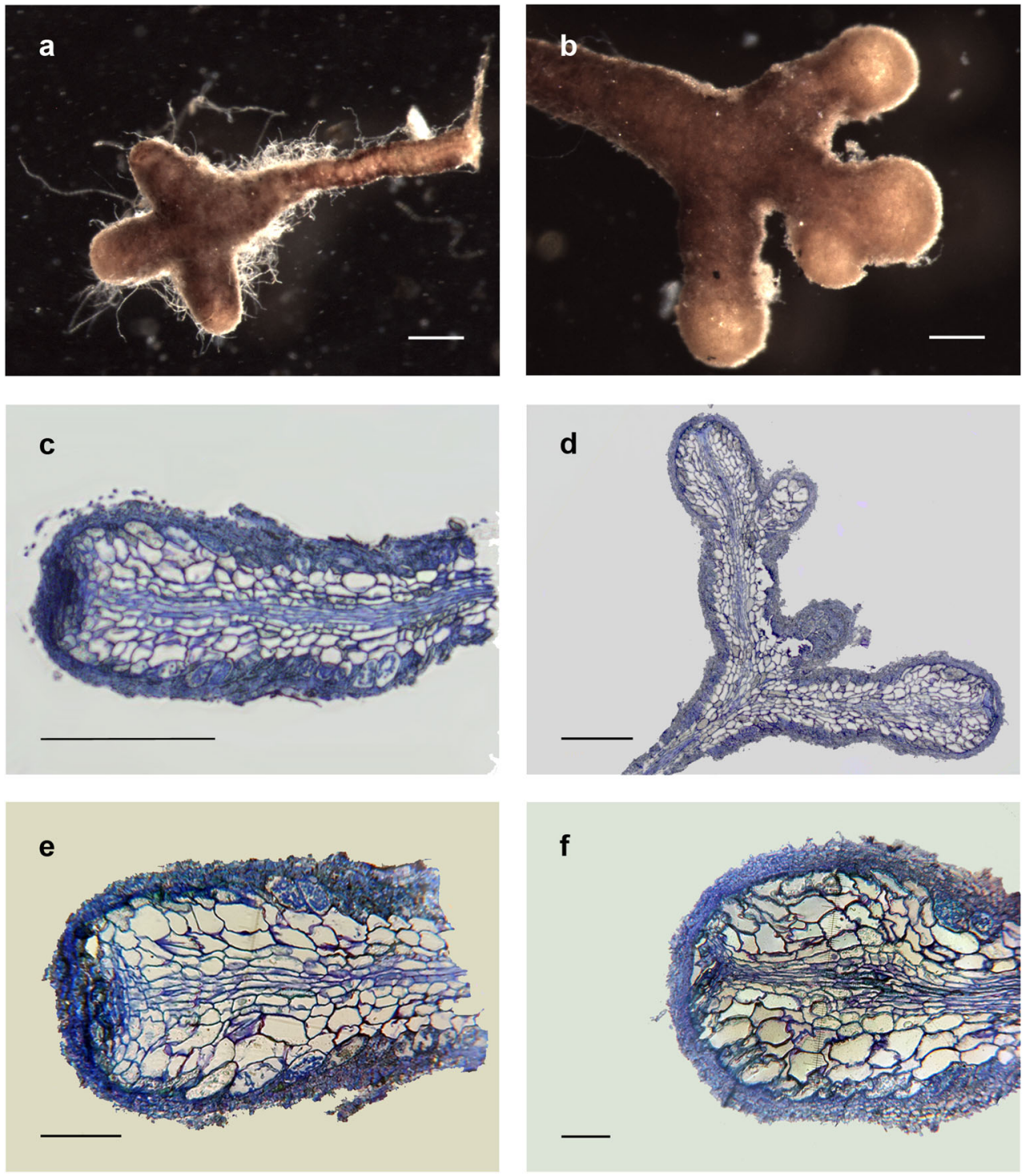

the rhizodermal cells almost completely colonized by hyphal coils, which became less frequent or absent towards the apex of tips. Colonized cells were inflated with the typical "fish bone" appearance as in ectomycorrhizae (Smith and Read 2008; Balestrini and Kottke 2017). Hyphae of both species never colonized the cortical cell layers by Hartig net or hyphal coils. Tuber aestivum mycorrhizal tips showed a 3-4 celllayer mantle thicker (Table 1, Figs. 2Sc, e), while only 1 to 3 layers were observed in T. melanosporum mycorrhizal tips (Figs. 2Sd, f). Most of T. melanosporum mycorrhizae did not show any type of fungal structure (mantle, Hartig net or hyphal coils) at the root apex or, rarely, a one-layered mantle (Table 1).

Twelve months after inoculation, mycorrhizae showed a 34 layers continuous mantle regardless the truffle species (Fig. 1c-f). Hartig net and hyphal coils were also spread at the root apex although the level of intra-cellular colonization was less evident than that present in the older regions of mycorrhizae.
Mantle thickness consistently increased in any part of mycorrhizal tips regardless of the truffle species (Table 1). The twoway ANOVA with robust estimators confirmed the effect of

Table 1 Mantle thickness of $T$. aestivum and T. melanosporum mycorrhizae, 6 and 12 months after inoculation, at the proximal and distal parts of tips $(n=90)$

\begin{tabular}{|c|c|c|c|c|}
\hline \multirow[t]{3}{*}{ Time after inoculation } & \multicolumn{4}{|c|}{ Mantle thickness $(\mu \mathrm{m})$} \\
\hline & \multicolumn{2}{|l|}{ T. aestivum } & \multicolumn{2}{|c|}{ T. melanosporum } \\
\hline & Proximal & Distal & Proximal & Distal $^{*}$ \\
\hline 6 months & $14.3 \pm 3.2$ & $10.7 \pm 2.9 \mathrm{a}$ & $15.7 \pm 4.4$ & $7.4 \pm 2.3 \mathrm{a}$ \\
\hline 12 months & $19.2 \pm 0.2$ & $17.1 \pm 4.7 b$ & $19.1 \pm 0.2$ & $22.2 \pm 5.2 b$ \\
\hline
\end{tabular}

${ }^{*}$ T. melanosporum mycorrhizae without a mantle in the distal part of tips were excluded from the measurement; different letters on the same column indicate significant differences for $P>0.05$ 
time and position on mantle thickness for both species $(P \leq$ 0.05). Mantle thickness at 6 and 12 months was significantly different in the distal parts $(P \leq 0.05)$ for both species, but not in the proximal parts $(P \geq 0.05)$ (Table 1 and Fig. 4S).

Ultrastructural observations were performed on 6-monthold mycorrhizal tips, mostly to verify the intracellular colonization (Fig. 2). In addition to the development of a Hartig net
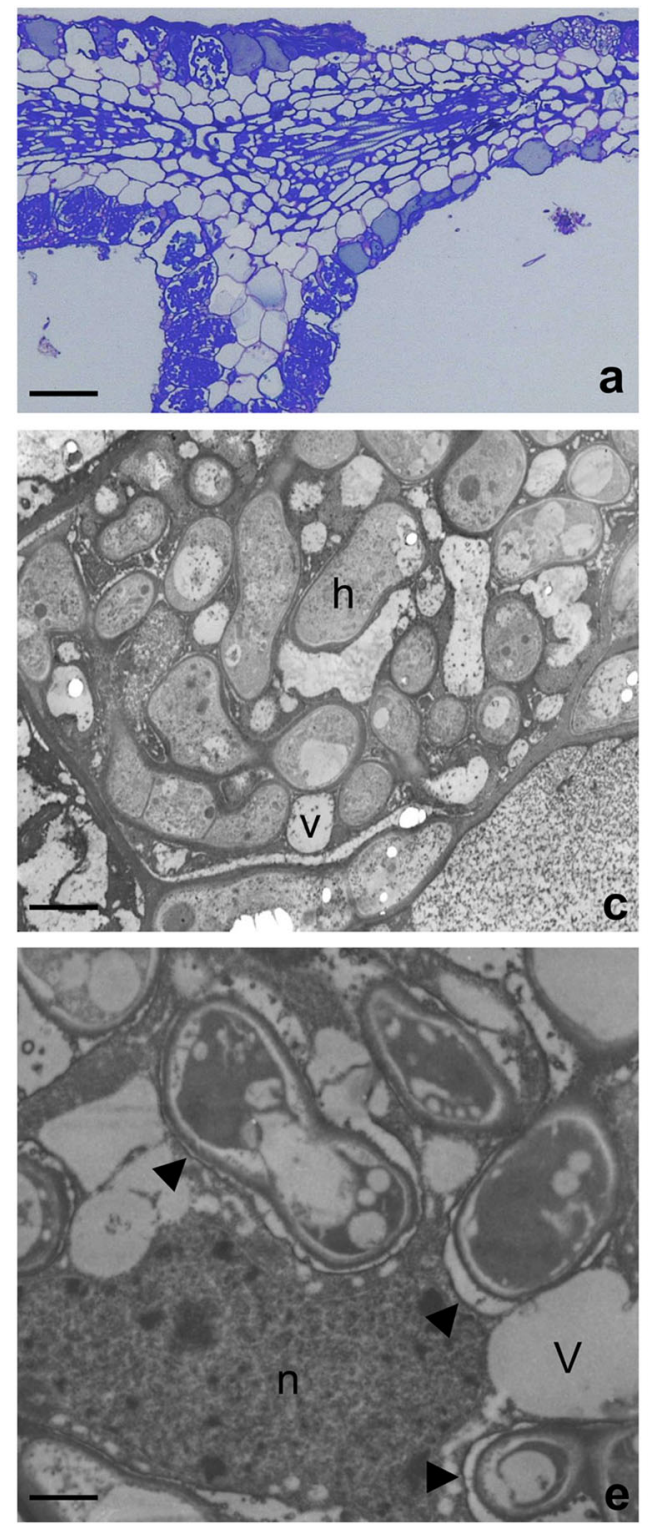

Fig. 2 Ultrastructural features of 6-month-old arbutoid mycorrhizae between A. unedo and T. melanosporum $(\mathbf{a}, \mathbf{c}, \mathbf{e})$ and T. aestivum $(\mathbf{b}, \mathbf{d}, \mathbf{f})$, respectively. a-b Longitudinal section of T. melanosporum (a) and T. aestivum (b) arbutoid mycorrhizae showing a thin mantle. Mantle hyphae penetrate between rhizodermal cells to form the Hartig net (arrows) and colonize rhizodermal cells (asterisks). Hyphal chains forming the Hartig net are particularly evident in T. melanosporum mycorrhiza (a), while they are less evident in the same region of $T$. borchii ones (b). Bars correspond to $40 \mu \mathrm{m}$ (a) and $50 \mu \mathrm{m}$ (b). c Transmission electron picture showing a rhizodermal cell containing fungal hyphae (h) in a mature T. melanosporum mycorrhiza. Small vacuoles (v) are evident inside the cells. Bar corresponds to $2 \mu \mathrm{m}$. d Transmission electron picture
(Fig. 2a, b), hyphae can penetrate rhizodermal cells, growing and branching inside them to form the coil structures typical of ecto-endomycorrhizae (Fig. 2a, b). In this area, in agreement with previous observations (Fusconi and Bonfante-Fasolo 1984), host cells show the presence of vacuoles with electron-dense material, probably tannins (Fig. 2c). It is worth noting that, during cell colonization, the host vacuoles are split
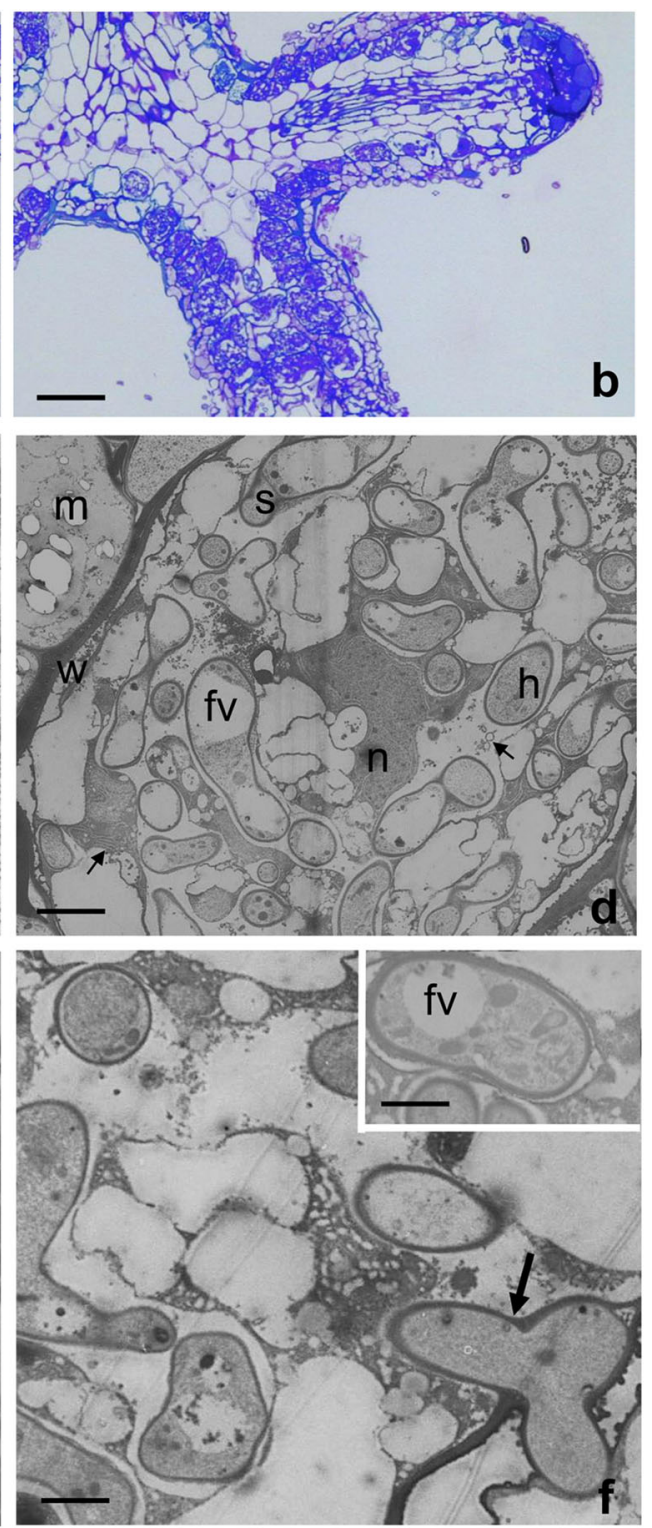

of a T. aestivum colonized host cell. Membranous systems are evident in the host cell cytoplasm as well as small vesicles (arrows) and an irregular shaped nucleus (n) positioned at the centre of the cell. Hyphae show septa with Woronin bodies (s) as well as vacuoles (fv). m, mantle; w, host cell wall. Bar corresponds to $2.5 \mu \mathrm{m}$. e Magnification of T. melanosporum intracellular hyphae. An electron-transparent interface space, delimited by the fungal cell wall and the host plasmalemma, is evident around the fungal hyphae (arrowheads). $\mathrm{n}$, plant nucleus. Bar corresponds to $1 \mu \mathrm{m}$. $\mathbf{f}$ Magnification of a T. aestivum colonized cell. A penetration point is evident (arrow). The interface space is evident around a T. aestivum intracellular hypha. Bars correspond to $1.8 \mu \mathrm{m}$ (f) and $1 \mu \mathrm{m}$ (inset) 
in smaller ones by the intracellular invasion by the fungal hyphae (Fig. 2c). Vesicles are evident in the host cytoplasm, mainly in T. aestivum mycorrhizae (Fig. 2d). The plant nucleus, as in other endomycorrhizae, has an irregular shape and can occupy a central position (Fig. 2d). Intracellular hyphae also showed a living and active cytoplasm, with small vacuoles, which contain electron-dense globular bodies (probably protein bodies), vesicles and mitochondria (Fig. 2). The walls of the intracellular hyphae are still formed by an electrontransparent inner layer and an electron-dense outer one, as typical for the truffle cell wall (Balestrini et al. 2012). The intracellular interface between the fungal hyphae and the host cells is characterized by an electron-transparent space where a fibrillar material can be present (Fig. 2). Differences in the interface features between the two fungal species, i.e. a more evident electron-dense loose material around the T. melanosporum hyphae, were also observed (Fig. 2c, e vs Fig. 2d, f). Pectins were not detected by the JIM5, JIM7 and LM19 antibodies on the interface material surrounding the truffle hyphae, independently from the considered fungal species.

\section{Discussion}

The present study shows the possibility to obtain mature arbutoid mycorrhizae between $T$. aestivum and T. melanosporum with A. unedo in controlled conditions and analysed the development of mycorrhizal symbiosis over a period of 12 months. Additionally, ultrastructural description of the mycorrhizae after 6 months from inoculation was performed. The description of arbutoid mycorrhizae was already reported in two Arbutus species, A. unedo and A. menziesii, mainly in combination with basidiomycetes (Massicotte et al. 1993; Navarro et al. 2009, 2011; Gomes et al. 2016; Kühdorf et al. 2016), while only a few reports focused on ascomycetes such as truffle.

Arbutoid mycorrhizae formed by T. borchii were described by Lancellotti et al. (2014) who observed the typical characteristics of $T$. borchii ectomycorrhizae but with an intracellular colonization. Tuber aestivum and T. melanosporum arbutoid mycorrhizae are also typical arbutoid mycorrhizae with anatomical features characteristic of the respective ectomycorrhizae. Apart from the intracellular colonization, the only difference seems to be the longer time required to form fully developed arbutoid mycorrhizae with respect to that required to produce their ectomycorrhizae in greenhouse conditions (usually 3 to 6 months after inoculation). In particular, both species took more than 6 months to form cruciform branched mycorrhizae with a completely formed mantle and typical cystidia. The symbiosis development seems to be particularly slow for $T$. melanosporum, which has difficulties to follow the elongation of the young root tips. Possibly,
T. melanosporum has a lower affinity for A. unedo than T. aestivum or T. borchii. However, further mycorrhization trials in different growth conditions should be carried out to confirm this observation.

Mature T. melanosporum and T. aestivum arbutoid mycorrhizae showed tip dimensions similar to those reported for T. borchii-A. unedo association, and for the corresponding ectomycorrhizae, with the exception of the tip diameter which seem to be slightly greater in T. borchii arbutoid mycorrhizae and pine ectomycorrhizae (Zambonelli et al., 1993, 1995; Granetti, 1995; Lancellotti et al., 2014). In agreement with previous observation on arbutoid mycorrhizae formed by Lactarius deliciosus (Gomes et al. 2016), Pisolithus tinctorius or Piloderma bicolor (Massicotte et al. 1993), a thick mantle is also formed by Tuber species (see also Lancellotti et al. 2014, for $T$. borchii). This is a different feature with respect to arbutoid mycorrhizae synthetized between $A$. unedo and an unknown ascomycete after Fusconi and Bonfante-Fasolo (1984).

Although in ectomycorrhizae the fungus usually remains apoplastic (Balestrini and Kottke 2017), the occurrence of truffle hyphae penetrating inside the host cells has been already reported for orchid roots (Selosse et al., 2004) and in vitro colonization systems with T. borchii (Montanini et al. 2003; Miozzi et al. 2005), which has been described to penetrate and colonize some senescent host cells in association with Cistus incanus (Miozzi et al. 2005). Pacioni et al. (2014) also reported the in vitro development and maintenance of endomycorrhizal associations of two Tuber species with transformed roots of $C$. incanus, confirming the capacity for these fungi to penetrate the host cells, at least under suitable conditions. However, histological observations of A. unedo mycorrhizae showed a different scenario, with the rhizodermal cells completely filled with the mycorrhizal fungus (Giovannetti et al. 1990). The same picture has been found in the truffle arbutoid mycorrhizae, where intracellular hyphal complexes were observed in rhizodermal cells with both T. aestivum and T. melanosporum. It is worth noting that arbutoid mycorrhizae are formed mainly by ECM fungi (Massicotte et al. 1993; Trevor et al. 2001). Although morphological observations on several ecto-endomycorrhizae were performed, ultrastructural analyses were not largely investigated. Our observations confirm previous studies (Fusconi and Bonfante-Fasolo 1984), showing a rearrangement of host cells and the creation of an interface compartment as observed for typical endosymbioses. Thus, describing the plant/fungus interface of arbutoid mycorrhizae, in addition to the typical ECM interface, where the plant and fungal cell wall are in direct contact, an additional interface compartment typical of endomycorrhizae is formed around the intracellular hyphae (Fusconi and Bonfante-Fasolo 1984). Our immunolabelling experiments with antibodies recognizing pectins at a different methylation degree suggest that this plant 
cell wall compound is not present in the interface matrix surrounding the intracellular hyphae. Pectins were found to be present in the interface compartment of intracellular mycorrhizal symbiosis (Balestrini and Bonfante 2014). However, the nature of the interface compartment is also related to the peripheral cell wall composition (Balestrini et al. 1996). A lack or a poor reaction with JIM5 and JIM7 antibodies was already observed in Ericaceae (Carney and Ashford 2002), suggesting negligible amounts of unesterified pectin and pectin with a low methyl-esterification degree. Here, a labelling was only sporadically observed on the peripheral cell wall using JIM5 as a probe (results not shown). In orchid mycorrhizae, the absence of epitopes recognized by JIM5 was reported at the interface between Limodorum abortivum and its Russula symbiont, which is the dominant fungal partner of $L$. abortivum, while pectin was found in the region surrounding the intracellular hyphae of Ceratobasidium (Paduano et al. 2011), suggesting that plant responses towards distinct mycorrhizal fungal partners can vary. Interestingly, truffles, as the fungi belonging to the genus Russula, are well known for their ECM phenotype on tree species. It is also worth noting that in truffle ectomycorrhizae, a localized degradation of pectin seems to occur during fungal growth through the middle lamella, in agreement with the expression of fungal genes acting on these polysaccharides, as observed in the T. melanosporum-Corylus avellana association (Sillo et al. 2016). Thus, further analyses are needed to improve our observations and to characterize the interfaces occurring in ectoendomycorrhizae, i.e. using probes for different cell wall components as well as performing molecular analyses on cell wall degrading enzyme expression in ecto-endomycorrhizae. In addition, the possibility to have both ECM and arbutoid mycorrhizae with the same fungal partner is a great opportunity to study the variability in the symbiosis establishment and functioning.

However, although the establishment of symbiosis with A. unedo seems to be a common feature in the genus Tuber, it is necessary to verify whether the symbiosis with T. aestivum and T. melanosporum is common in natural conditions. Soil composition should not be the limiting factor. Tuber aestivum can grow in a wide range of soils (Robin et al. 2016), while T. melanosporum prefers dolomitic limestones and calcareous sandstones with a $\mathrm{pH}>7$ (Jaillard et al. 2016). For its part, A. unedo grows in different soil types, and local ecotypes have been found on basic and calcareous soils throughout the Mediterranean basin (Başlar et al. 2002; Torres et al. 2002). However, the ability of T. aestivum and T. melanosporum to establish symbiosis with $A$. unedo increases the number of host plant/truffle combinations suitable for truffle mycorrhization. They are the most cultivated truffle species in the world, and their distribution is increasing from year to year as "monocrop". The possibility of using host plants that provide secondary products (honey and fruits in the case of A. unedo) in addition to truffles can be considered as an improvement to the traditional concept of truffle cultivation. Multi-cropping of economically valuable plants and truffles represents an alternative for rural and disadvantaged economies by providing farmers a multiple source of income (Benucci et al. 2012; Álvarez-Lafuente et al. 2018).

It is well known that mycorrhizal fungi improve plant fitness and protect them from environmental stresses. A role for ecto-endomycorrhizal fungi, such as the desert truffle Terfezia claveryi Chatin, in reducing negative effects of drought stress on Helianthemum almeriense, through physiological and nutritional mechanisms, has been suggested before (Morte et al. 2000). This point could be further investigated also for truffle arbutoid symbiosis, to verify its potential as multipurpose forestations in Mediterranean semi-arid regions. Tuber melanosporum and T. aestivum are typical Mediterranean truffles, and they are also adapted to warm climate although T. melanosporum does not tolerate extreme summer drought (Kagan-Zur et al. 2012; Zambonelli et al. 2014; Le Tacon 2016). The production of $A$. unedo plants inoculated with selected truffle strains tolerant to drought and high temperatures can represent an efficient approach to successfully cultivate truffles in semi-arid climates (Leonardi et al. 2017). As highlighted above, besides the applied aspects, the availability of ectomycorrhizae and ecto-endomycorrhizae with the same fungal species represents an important point to improve our knowledge on the mycorrhizal toolkit common to different symbiotic strategies.

Funding information Open access funding provided by Università degli Studi dell'Aquila within the CRUI-CARE Agreement.

Open Access This article is licensed under a Creative Commons Attribution 4.0 International License, which permits use, sharing, adaptation, distribution and reproduction in any medium or format, as long as you give appropriate credit to the original author(s) and the source, provide a link to the Creative Commons licence, and indicate if changes were made. The images or other third party material in this article are included in the article's Creative Commons licence, unless indicated otherwise in a credit line to the material. If material is not included in the article's Creative Commons licence and your intended use is not permitted by statutory regulation or exceeds the permitted use, you will need to obtain permission directly from the copyright holder. To view a copy of this licence, visit http://creativecommons.org/licenses/by/4.0/.

\section{References}

Agerer R (1995) Anatomical characteristics of identified ectomycorrhizas: an attempt towards a natural classification. In: Varma A, Hock B (eds) Mycorrhiza. Springer, Berlin Heidelberg, pp 685-734. https://doi.org/10.1007/978-3-662-08897-5_29 
Álvarez-Lafuente A, Benito-Matías LF, Peñuelas-Rubira JL, Suz LM (2018) Multi-cropping edible truffles and sweet chestnuts: production of high quality Castanea sativa seedlings inoculated with Tuber aestivum, its ecotype T. uncinatum, T. brumale, and T. macrosporum. Mycorrhiza 28:29-38. https://doi.org/10.1007/ s00572-017-0805-9

Balestrini R, Bonfante P (2014) Cell wall remodeling in mycorrhizal symbiosis: a way towards biotrophism. Front Plant Sci 5:237. https://doi.org/10.3389/fpls.2014.00237

Balestrini R, Hahn MG, Faccio A, Mendgen K, Bonfante P (1996) Differential localization of carbohydrate epitopes in plant cell walls in the presence and absence of arbuscular mycorrhizal fungi. Plant Physiol 111:203-213. https://doi.org/10.1104/pp.111.1.203

Balestrini R, Kottke I (2017) Structure and development of ectomycorrhizal roots. In: Martin F (ed) Molecular Mycorrhizal Symbiosis. Wiley-Blackwell, Oxford UK, pp 47-61

Balestrini R, Sillo F, Kohler A, Schneider G, Faccio A, Tisserant E, Martin F, Bonfante P (2012) Genome-wide analysis of cell wallrelated genes in Tuber melanosporum. Curr Genet 58:165-177. https://doi.org/10.1007/s00294-012-0374-6

Başlar S, Doğan Y, Mert H (2002) Studies on the soil-plant interactions of two Arbutus L. species in West Anatolia. Botanika Chronika 15:6374

Benucci GMN, Bonito G, Baciarelli-falini L, Bencivenga M (2012) Mycorrhization of Pecan trees (Carya illinoinensis) with commercial truffle species: Tuber aestivum Vittad. and Tuber borchii Vittad. Mycorrhiza 22:383-392. https://doi.org/10.1007/s00572-011-0413$\mathrm{z}$

Bonito GM, Gryganskyi AP, Trappe JM, Vilgalys R (2010) A global meta-analysis of Tuber ITS rDNA sequences: species diversity, host associations and long-distance dispersal. Mol Ecol 19:4994-5008. https://doi.org/10.1111/j.1365-294x.2010.04855.x

Cairney JWG, Ashford AE (2002) Biology of mycorrhizal associations of epacrids (Ericaceae). New Phytol 154:305-326. https://doi.org/10. 1046/j.1469-8137.2002.00398.x

Fusconi A, Bonfante-Fasolo P (1984) Ultrastructural aspects of hostendophyte relationships in Arbutus unedo L. mycorrhizas. New Phytol 96:397-410. https://doi.org/10.1111/j.1469-8137.1984. tb03575.x

Giovannetti M, Lioi L, Picci G (1990) Host and non-host relationships between Arbutus unedo L. and mycorrhizal fungi. Agric Ecosyst Environ 29:169-172. https://doi.org/10.1016/0167-8809(90) 90271-E

Gomes F, Suárez D, Santos R, Silva M, Gaspar D, Machado H (2016) Mycorrhizal synthesis between Lactarius deliciosus and Arbutus unedo L. Mycorrhiza 26:177-188. https://doi.org/10.1007/s00572015-0656-1

Granetti B (1995) Caratteristiche morfologiche, biometriche e strutturali delle micorrize di Tuber di interesse economico. Micol Ital 24(2): 101-117

Gryndler M (2016) True truffle host diversity. In: Zambonelli A, Iotti M, Murat C (eds) True Truffle (Tuber spp.) in the World, Soil Biology, vol, vol 47. Springer International Publishing, Cham, pp 267-281. https://doi.org/10.1007/978-3-319-31436-5_16

Iotti M, Zambonelli A (2006) A quick and precise technique for identifying ectomycorrhizas by PCR. Mycol Res 110:60-65. https://doi. org/10.1016/j.mycres.2005.09.010

Jaillard B, Oliach D, Sourzat P, Colinas C (2016) Soil characteristics of Tuber melanosporum habitat. In: Zambonelli A, Iotti M, Murat C (eds) True Truffle (Tuber spp.) in the World, Soil Biology, vol 47. Springer International Publishing, Cham, pp 169-190. https://doi. org/10.1007/978-3-319-31436-5 11

Kagan-Zur V, Turgeman T, Sitrit Y, Danai O, Luzzati Y, Bustan A, RothBejerano N, Masaphy S (2012) Introduced Tuber aestivum spreading spontaneously in Israel. Acta Mycol 47:175-177
Kennedy PG, Smith DP, Horton TR, Molina RJ (2012) Arbutus menziesii (Ericaceae) facilitates regeneration dynamics in mixed evergreen forests by promoting mycorrhizal fungal diversity and host connectivity. Am J Bot 99:1691-1701. https://doi.org/10.3732/ajb. 1200277

Kühdorf K, Münzenberger B, Begerow D, Gómez-Laurito J, Hüttl RF (2016) Arbutoid mycorrhizas of the genus Cortinarius from Costa Rica. Mycorrhiza 26:497-513. https://doi.org/10.1007/s00572-0160688-1

Lancellotti E, Iotti M, Zambonelli A, Franceschini A (2014) Characterization of Tuber borchii and Arbutus unedo mycorrhizas. Mycorrhiza 24:481-486. https://doi.org/10.1007/s00572-014-05649

Lancellotti E, Iotti M, Zambonelli A, Franceschini A (2016) The Puberulum group sensu lato (whitish truffles). In: Zambonelli A, Iotti M, Murat C (eds) True Truffle (Tuber spp.) in the World. Soil Biology, vol 47. Springer International Publishing, Cham, pp 105124. https://doi.org/10.1007/978-3-319-31436-5_7

Leonardi P, Iotti M, Donati Zeppa S, Lancellotti E, Amicucci A, Zambonelli A (2017) Morphological and functional changes in mycelium and mycorrhizas of Tuber borchii due to heat stress. Fungal Ecol 29:20-29 https://doi.org/10.1016/j.funeco.2017.05.003

Le Tacon F (2016) Influence of climate on natural distribution of Tuber species and truffle production. In: Zambonelli A, Iotti M, Murat C (eds) True Truffle (Tuber spp.) in the World, Soil Biology, vol 47. Springer International Publishing, Cham, pp 153-167. https://doi. org/10.1007/978-3-319-31436-5 10

Lim TK (2012) Arbutus unedo. In: Lim TK (ed) Edible Medicinal And Non-Medicinal Plants: Volume 2. Fruits, Springer Netherlands, pp 444-451. https://doi.org/10.1007/978-94-007-1764-0 59

Massicotte HB, Melville LH, Molina R, Peterson RL (1993) Structure and histochemistry of mycorrhizae synthesized between Arbutus menziesii (Ericaceae) and two basidiomycetes, Pisolithus tinctorius (Pisolithaceae) and Piloderma bicolor (Corticiaceae). Mycorrhiza 3: 1-11. https://doi.org/10.1007/BF00213461

Mello A, Cantisani A, Vizzini A, Bonfante P (2002) Genetic variability of Tuber uncinatum and its relatedness to other black truffles. Environ Microbiol 4:584-594. https://doi.org/10.1046/j.1462-2920.2002. 00343.x

Miozzi L, Balestrini R, Bolchi A, Novero M, Ottonello S, Bonfante P (2005) Phospholipase A2 up-regulation during mycorrhiza formation in Tuber borchii. New Phytol 167:229-238. https://doi.org/10. 1111/j.1469-8137.2005.01400.x

Molina R, Trappe JM (1982) Lack of mycorrhizal specificity by the ericaceous hosts Arbutus menziesii and Arctostaphylos uva-ursi. New Phytol 90:495-509. https://doi.org/10.1111/j.1469-8137. 1982.tb04482.x

Montanini B, Betti M, Marquez AJ, Balestrini R, Bonfante P, Ottonello S (2003) Distinctive functional properties and expression profiles of glutamine synthetase from a plant symbiotic fungus. Biochem J 373: 357-368. https://doi.org/10.1042/BJ20030152

Morgado S, Morgado M, Plácido AI, Roque F, Duarte AP (2018) Arbutus unedo $\mathrm{L}$.: from traditional medicine to potential uses in modern pharmacotherapy. J Ethnopharmacol 225:90-102. https://doi.org/ 10.1016/j.jep.2018.07.004

Morte A, Lovisolo C, Schubert A (2000) Effect of drought stress on growth and water relations of the mycorrhizal association Helianthemum almeriense-Terfezia claveryi. Mycorrhiza 10:115119. https://doi.org/10.1007/s005720000066

Münzenberger B, Kottke I, Oberwinkler F (1992) Ultrastructural investigations of Arbutus unedo-Laccaria amethystea mycorrhiza synthesized in vitro. Trees 7:40-47. https://doi.org/10.1007/BF00225230

Navarro A, Bañon S, Olmos E, Sánchez-Blanco MJ (2007a) Effects of sodium chloride on water potential components, hydraulic conductivity, gas exchange and leaf ultrastructure of Arbutus unedo plants. 
Plant Sci 172:473-480. https://doi.org/10.1016/j.plantsci.2006.10. 006

Navarro A, Sánchez-Blanco MJ, Bañón S (2007b) Influence of paclobutrazol on water consumption and plant performance of Arbutus unedo seedlings. Sci Hortic 111:133-139. https://doi.org/ 10.1016/j.scienta.2006.10.014

Navarro A, Sánchez-Blanco MJ, Morte A, Bañón S (2009) The influence of mycorrhizal infection on water and nutritional status of Arbutus unedo treated and not treated with paclobutrazol. Environ Exp Bot 66:362-371. https://doi.org/10.1016/j.envexpbot.2009.04.005

Navarro García A, del Pilar Bañón Árias S, Morte A, Sánchez-Blanco MJ (2011) Effects of nursery preconditioning through mycorrhizal inoculation and drought in Arbutus unedo L. plants. Mycorrhiza 21: 53-64. https://doi.org/10.1007/s00572-010-0310-x

Ouanphanivanh N, Merényi Z, Orczán AK, Bratek Z, Szigeti Z, Illyés Z (2008) Could orchids indicate truffle habitats? Mycorrhizal association between orchids and truffles. Acta Biologica Szegediensis 52: 229-232

Pacioni G, Ragnelli AM, Aimola P, Leonardi M, Marinucci D, Bejerano R., Kagan-Zur V (2014) Endomycorrhiza and epidermal ectomycorrhiza produced in vitro by two species of Tuber on transformed Cistus incanus roots. Int J Plant Biol Res 2(4):1021.

Paduano C, Rodda M, Ercole E, Girlanda M, Perotto S (2011) Pectin localization in the Mediterranean orchid Limodorum abortivum reveals modulation of the plant interface in response to different mycorrhizal fungi. Mycorrhiza 21:97-104. https://doi.org/10.1007/ s00572-010-0315-5

Plácito F, Ferreira I, Clemente M, Figueiredo P, Barrento MJ, Machado H, Gomes F (2018) Mycorrhizal synthesis between Tuber borchii and Arbutus unedo L. seedlings and micropropagated plants. Acta Hortic 1224:91-100. https://doi.org/10.17660/actahortic.2018. 1224.13

Robin C, Goutal-Pousse N, Le Tacon F (2016) Soil characteristics for Tuber aestivum (Syn. T. uncinatum). In: Zambonelli A, Iotti M, Murat C (eds) True Truffle (Tuber spp.) in the World. Soil Biology, vol 47. Springer International Publishing, Cham, pp 211231. https://doi.org/10.1007/978-3-319-31436-5 13

Rubini A, Paolocci F, Granetti B, Arcioni S (1998) Single step molecular characterization of morphologically similar black truffle species. FEMS Microbiol Lett 164:7-12. https://doi.org/10.1111/j.15746968.1998.tb13060.x

Santiso X, Lopez L, Retuerto R, Barreiro R (2015) Population structure of a widespread species under balancing selection: the case of Arbutus unedo L. Front Plant Sci 6:1264. https://doi.org/10.3389/fpls.2015. 01264

Selosse MA, Faccio A, Scappaticci G, Bonfante P (2004) Chlorophyllous and achlorophyllous specimens of Epipactis microphylla (Neottieae, Orchidaceae) are associated with ectomycorrhizal septomycetes, including truffles. Microb Ecol 47:416-426. https://doi.org/10. 1007/s00248-003-2034-3

Schneider-Maunoury L, Leclercq S, Clément C, Covès H, Lambourdière J, Sauve M, Richard F, Selosse MA, Taschen E (2018) Is Tuber melanosporum colonizing the roots of herbaceous, nonectomycorrhizal plants? Fungal Ecol 31:59-68. https://doi.org/10. 1016/j.funeco.2017.10.004

Schneider-Maunoury L, Deveau A, Moreno M, Todesco F, Belmondo S, Murat C, Courty PE, Jąkalski M, Selosse MA (2020) Two ectomycorrhizal truffles, Tuber melanosporum and T. aestivum, endophytically colonise roots of non-ectomycorrhizal plants in natural environments. New Phytol 225:2542-2556. https://doi.org/10. 1111/nph.16321

Sillo F, Fangel JU, Henrissat B, Faccio A, Bonfante P, Martin F, Willats WGT, Balestrini R (2016) Understanding plant cell-wall remodelling during the symbiotic interaction between Tuber melanosporum and Corylus avellana using a carbohydrate microarray. Planta 244: 347-359. https://doi.org/10.1007/s00425-016-2507-5

Smith SE, Read DJ (2008) Mycorrhizal symbiosis, 3rd edn. Academic, Amsterdam

Torres JA, Valle F, Pinto C, García-Fuentes A, Salazar C, Cano E (2002) Arbutus unedo L. communities in southern Iberian Peninsula mountains. Plant Ecol 160:207-223. https://doi.org/10.1023/A: 1015864821706

Trevor E, Yu JC, Egger KN, Peterson RL (2001) Ectendomycorrhizal associations - characteristics and functions. Mycorrhiza 11:167177. https://doi.org/10.1007/s005720100110

Zambonelli A, Donnini D, Rana GL, Fascetti S, Benucci GMN, Iotti M, Morte A, Khabar L, Bawadekji A, Piattoni F, Compagno R, Venturella G (2014) Hypogeous fungi in Mediterranean maquis, arid and semi-arid forests. Plant Biosyst 148:392-401. https://doi. org/10.1080/11263504.2013.877537

Zambonelli A, Iotti M, Hall I (2015) Current status of truffle cultivation: recent results and future perspectives. Ital J Mycol 44:31-40. https:// doi.org/10.6092/issn.2465-311X/5593

Zambonelli A, Salomoni S, Pisi A (1993) Caratterizzazione anatomomorfologica delle micorrize di Tuber spp. su Quercus pubescens Willd. Micol Ital 22(3):73-90

Zambonelli A, Salomoni S, Pisi A (1995) Caratterizzazione anatomomorfologica e micromorfologica delle micorrize di Tuber borchii Vitt., Tuber aestivum Vitt., Tuber mesentericum Vitt., Tuber brumale Vitt. Tuber melanosporum Vitt. su Pinus pinea. L. Micol Ital 24(2):119-137

Publisher's note Springer Nature remains neutral with regard to jurisdictional claims in published maps and institutional affiliations. 